\title{
El desarrollo de industrias de alta tecnología en países emergentes. La biotecnología en Argentina desde un enfoque de redes
}

\author{
Lilia Inés Stubrin \\ Facultad de Ciencias Económicas - \\ Universidad Nacional del Litoral \\ Email: liliastubrin@gmail.com
}

\section{Resumen}

Esta tesis estudia, tomando el caso de la biotecnología en Argentina, cómo las actividades de alta tecnología se desarrollan en países emergentes. Se utiliza un enfoque de redes. Los resultados indican que el desarrollo de la biotecnología, tanto en el ámbito industrial como en el científico, depende tanto de la creación y difusión de conocimiento a nivel local, como de los mecanismos por los cuales el conocimiento se difunde con pares en el extranjero (fundamentalmente en países líderes en biotecnología). Los resultados tienen implicancias para comprender mejor el proceso de cambio técnico en economías emergentes.

\footnotetext{
Abstract

This thesis studies, based on the case of biotechnology in Argentina, the development of high tech activities in emerging countries. It adopts a network approach. Results show that the development of biotechnology, in the industrial and scientific sphere, is based not only on the creation and diffusion of knowledge at local level but also on external knowledge flows (mostly created with peers located in the leading biotechnology regions). These results has implications to better understand the process of technical change in emerging economies.
} 